\title{
A new high-resolution aeromagnetic dataset over central Ayrshire: insights into the concealed geology \\ J P Busby ${ }^{1 *}$, M C Akhurst ${ }^{2}$ and A S D Walker ${ }^{1}$ \\ ${ }^{1}$ British Geological Survey, Keyworth, Nottingham, NG12 5GG \\ ${ }^{2}$ British Geological Survey, West Mains Road, Edinburgh, EH9 3LA \\ * corresponding author, e-mail jpbu@bgs.ac.uk
}

\section{Synopsis}

High-resolution aeromagnetic data have been acquired over central Ayrshire as part of a multi-component environmental and resource survey. The data were recorded along easterly orientated flight lines at $200 \mathrm{~m}$ separation and show a very marked improvement in resolution over the pre-existing aeromagnetic data for the region. The distribution of the extensive volcanic and intrusive igneous rocks in the near sub-surface is defined more accurately, many new features are recognised and features distinguished in the pre-existing aeromagnetic data are now seen to be laterally continuous. Northwesterly trending lineaments are clearly defined and most can be attributed to Palaeogene dykes, the majority of which are reversely magnetised. Depth to source solutions and modelling suggest that even though the dykes have a limited width at outcrop, their widths increase with depth. Permo-Carboniferous easterly trending dykes are not well resolved in the new aeromagnetic data. This is most likely due to a low amplitude resultant magnetic vector that combined with the easterly-oriented flight lines results in few large anomalies. One significant northwesterly trending lineament is interpreted as the trace of the Cleveland Dyke across the Midland Valley. These new data should be of value to the extractive and water industries and assist in the planning and sustainable management of these resources. 


\section{Introduction}

In early October 2004 high-resolution airborne magnetic data were acquired over part of Ayrshire in southwest Scotland. These data are part of a multi-component survey flown for environmental and resource objectives that also included electromagnetic and radiometric sensors. The survey area was chosen to prove the utility of high-resolution survey methods in an area of recently completed and ongoing geological resurvey of bedrock and superficial deposits (British Geological Survey, 1999a \& b; 2002a \& b; 2005) and 3D computer modelling of subsurface coal-bearing strata. High-resolution magnetic data are able to map intrusive and extrusive igneous rocks in the shallow sub-surface and are especially useful in regions that have experienced a number of phases of volcanic activity and dyke emplacement, such as the Midland Valley of Scotland (Bell \& Williamson, 2002; Read et al., 2002; Monaghan \& Pringle, 2004; Monaghan \& Parrish, 2006). Knowledge of the location of dykes is important for several reasons. Development of opencast coal mining is hindered by the presence of dykes and the unexpected discovery of dykes after a mine has started production reduces its profitability. Similar problems are likely to be encountered in the development of aquifers for water abstraction where dykes may play a major role in defining aquifer boundaries. Dykes can also be a resource where they may be the most accessible source for hard rock aggregate.

The magnetic data were acquired by the Geological Survey of Finland (GTK), and the British Geological Survey (BGS) as a joint venture. The survey area is approximately rectangular and located between the west coast and BNG (British National Grid) easting 271 $\mathrm{km}$ and northings 615 to $640 \mathrm{~km}$ (Fig. 1). The topography in the west is at lower elevations and includes the urban areas of Kilmarnock, Irvine, Troon and Cumnock. Prestwick and Ayr were not included within the survey area. In the east there is higher ground that is mainly moorland. Flight lines were oriented east to west and were spaced at $200 \mathrm{~m}$ separation. The survey was flown with a fixed wing De Havilland Twin Otter at a nominal height above 
ground level of $56 \mathrm{~m}$ over rural areas and $250 \mathrm{~m}$ over urban centres and at a normal flight speed of $220 \mathrm{~km} \mathrm{~h}^{-1}$. Two sets of magnetic measurements were collected with Scintrex CS-2 caesium magnetometers mounted in each of the wingtips. The magnetometers were sampled at 10 times per second, resulting in a magnetic measurement approximately every $7 \mathrm{~m}$ of survey flight. The survey was flown between $29^{\text {th }}$ September and $12^{\text {th }}$ October 2004 and the total on-survey line kilometres flown were $4,860 \mathrm{~km}$.

This paper presents an assessment and interpretation of the magnetic data and demonstrates the potential of these data for enhancing our understanding of the concealed geology.

\section{The magnetic data}

During the survey a magnetic base station was operated and this was used to monitor for any excessive diurnal variations. A quality control variation of $10 \mathrm{nT}$ in 3 minutes was applied and if this was exceeded the flight was repeated once the diurnal variation had reduced to lower values. The base station data were used to remove any remaining diurnal variations and the daily secular variation. After the end of the survey the data were levelled using a method that does not require tie lines (Korhonen, 2005) and hence these were not flown during the survey. For presentation purposes the International Geomagnetic Reference Field has been removed and the resulting data are displayed as a colour shaded image in Fig. 2. Annotation on this image refers to interpreted features that are described in the sections below.

For comparison, Fig. 3 is an image of the existing aeromagnetic data for the region. These data were collected in 1959 and 1962 by Canadian Aeroservices and the Huntings Group, respectively. These data were collected along flight lines spaced approximately $2 \mathrm{~km}$ apart with tie lines every $10 \mathrm{~km}$ at a mean terrain clearance of $305 \mathrm{~m}$. Flight line orientation was north-south except for the northern segment of the survey where it was east-west. The data are displayed relative to a variant of the International Geomagnetic Reference Field 1990 (British Geological Survey, 1998). The longer wavelength features are reproduced well in this image and the overall magnetic character is the same as in Fig. 2. The significant 
difference of the new dataset is the increased resolution that defines the shorter wavelength anomalies. It should be noted that in Fig. 3 some of the shorter wavelength features are aliased (the under sampling results in parts of these anomalies being represented as longer wavelength features) and this could lead to erroneous interpretation.

\section{The geology of the survey area}

Most of the survey area is underlain by bedrock of Carboniferous age (Fig. 1). In the centre of the study area Upper Carboniferous (Pennsylvanian) Scottish Coal Measures Group sedimentary strata are overlain by the Permian Mauchline Volcanic and Mauchline Sandstone formations (Fig. 1). Lower Carboniferous (Mississippian) rocks comprise both sedimentary strata and volcanic rocks; the Clyde Plateau Volcanic Formation and the Troon Volcanic Member (Passage Formation) are toward the base and near the top of the sequence, respectively. Carboniferous bedrock unconformably overlies rocks of Silurian and Devonian ages. The outcrop of Carboniferous and older rocks is controlled by major fault structures of north-west to east-north-east trend (Fig. 1). Both the Inchgotrick and Bankhead faults juxtapose Lower Carboniferous strata with rocks of Silurian to Devonian ages and the Southern Upland Fault, in the south-east of the survey area, defines the southerly boundary of the Midland Valley of Scotland (Fig. 1). The sequence of rocks of late Silurian to early Devonian age includes the Duneaton Volcanic Formation (Fig. 1) and is intruded by younger Devonian (Thirlwall, 1988) granodioritic and dioritic rocks of the Distinkhorn Plutonic Complex (MacPherson et al., 2000). The Carboniferous rocks within the area of survey are known from mapping, incorporating coal mining data, to be intruded by many dykes, sills and volcanic vent rocks of Carboniferous to Permian age and, in addition, dykes and intrusions of Palaeogene age cut across all older rock units. The distribution of minor intrusions is less well-known in pre-Carboniferous rocks.

\section{Main magnetic features}


In Fig. 2 some of the highest magnetic values are found in the northeast of the image over the basaltic lavas of the Clyde Plateau Volcanic Formation (area A). Anomalies generally peak in the 200 to $500 \mathrm{nT}$ range, although some anomalies of up to $1000 \mathrm{nT}$ occur. Raised magnetic values continue to the west (area B), where many dykes and sills of late Carboniferous and post-Carboniferous age intrude the Coal Measures strata, and are bounded to the south by the Inchgotrick Fault (magnetic gradient C). The bedrock geology is Scottish Coal Measures Group, but the raised magnetic values with anomaly peaks of 50 to $200 \mathrm{nT}$ indicate that the Clyde Plateau Volcanic Formation rocks continue at depth. In the far northwest of the image a longer wavelength anomaly occurs (D), with values in the range 250 to $380 \mathrm{nT}$. This triangle-shaped anomaly appears to define the westward subsurface extent of the analcimedolerite (teschnitic) sill, of late Carboniferous to early Permian age that underlies the town of Irvine (Monro, 1999). The angular shape of the anomaly corresponds with the northwest and northeast orientation of faults mapped in this area (British Geological Survey, 2005).

To the south of the Inchgotrick Fault (C) is a broad region characterised by lower anomaly peak values, generally in the range +50 to $-50 \mathrm{nT}$. This marked contrast in the magnetic character across the Inchgotrick Fault (Fig. 1) confirms that the Clyde Plateau Volcanic Formation, present in the hangingwall sequence to the north, is not present to the south of the fault (Monro, 1999; MacPherson et al., 2000). This is consistent with the thickness variations in the volcanic formation across other faults of northeast trend inferred from gravity data (Mclean, 1966) or seismic data (Hall, 1974). Modelling of the earlier regional Bouger gravity and aeromagnetic survey data (Fig. 3) led Rollin (in Monro,1999) to terminate the 500 mthick Clyde Plateau Volcanic Formation against the Inchgotrick Fault. The volcanic formation was either thinned over the footwall block and eroded prior to deposition of later strata or the fault escarpment was a barrier to the southward extent of the lavas, as described by Monro (1999). Higher values, peaking at $1000 \mathrm{nT}$, occur in two zones on either side of the Inchgotrick Fault (E and F) and are associated with analcime-alkalai-dolerite (teschenitic) 
sills of Permo-Carboniferous age; the Caprington and Hillhouse sills underlie area E. A zone of higher values, with anomaly peaks in the range 50 to 200 nT coincides with the Duneaton Volcanic Formation (G) that consists of Upper Silurian to Lower Devonian basaltic and andesitic lavas. These values are terminated to the east at the outcrop of the underlying Swanshaw Sandstone Formation. This sandstone is characterised by a smooth magnetic zone (H) that on its eastern boundary has a very large magnetic gradient, where values increase from around 10 to a maximum of $900 \mathrm{nT}$. The gradient zone defines a north trending lineament that marks the western boundary of the Distinkhorn Plutonic Complex (I) (Fig 1). At outcrop of this composite granodioritic and dioritic body is a series of separate intrusions (MacPherson et al., 2000). However, the magnetic character indicates a single body at depth, clearly defines its southward extent and confirms that it becomes increasingly buried to the east. Consequently, the exact position of the eastern boundary in the subsurface is difficult to locate. In the centre of the image a series of linked, highly negative anomalies are associated with the Mauchline Volcanic Formation (area J). These negative anomalies suggest that the volcanic rocks have a large component of remanent magnetisation. However, farther north where there is also an outcrop of Mauchline Volcanic Formation (area K) the magnetic character is complicated by the intrusion of a Palaeogene sill and, presumed, dykes and faulting.

The Southern Upland Fault intersects the survey area in the far southeastern corner. A number of parallel fault structures, including the Glenmuir and Kennox faults, are part of the zone of faulting associated with reactivation of this major Caledonide structure (Fig. 1). The footwall block of the Glenmuir Fault (area L) is characterised by marked positive and negative magnetic anomalies, in contrast to the uniformly low zone of long wavelength anomaly (area M) of the hanging wall sequence. The latter is predominantly sedimentary strata of Siluro-Devonian and Carboniferous age and includes very little near-surface volcanic rocks, whereas Lower Carboniferous sandstone unconformably overlying 
volcaniclastic sandstone and basaltic andesite of the Duneaton Volcanic Formation of SiluroDevonian age crop out in the footwall block of the Glenmuir Fault. The footwall block of the Kennox Fault (area N) is similarly distinguished by a highly magnetic character, although the values of magnetic anomaly highs are less extreme, and are also underlain by a thicker sequence of Siluro-Devonian sandstone and underlying Duneaton Volcanic rocks. The high magnetic anomalies may have been generated, at least in part, by rocks concealed beneath the Lower Palaeozoic strata that are seen at outcrop. Kimbell (in Smith, 1999), attributed magnetic anomaly highs in the regional magnetic anomaly data (Fig. 3; BGS, 1999a) and bounded by the Glenmuir Fault as largely due to the presence of the Duneaton Volcanic Formation. The new more highly resolved data indicate that the relationship between magnetic anomaly highs and the Duneaton volcanic rocks is not as close as inferred from the earlier survey data. Concealed rocks that make a part contribution to the magnetic anomalies noted between the Southern Upland and Glenmuir faults would have to be of a highly magnetic character, as the overlying strata would be several hundreds of metres thick. These data support the view of Kimbell (in Smith, 1999) that very highly magnetic ophiolitic rocks may be concealed near the Southern Upland Fault, analogous to those of the Ballantrae Complex noted $60 \mathrm{~km}$ along strike to the south-west (Kimbell, in Floyd, 1999).

There are many positive anomalies of relatively small extent but high peak values in the southern part of the survey area south and west of the Mauchline Volcanic and Sandstone formations. These coincide with sills of late Carboniferous to early Permian dolerite to the south and Palaeogene alkalai olivine-dolerite (Prestwick-Mauchline Sill) to the west.

\section{Lineament analysis}

Magnetic lineaments are features that extend over considerable linear or arcuate dimensions. The identification of a lineament is dependent on the density of data coverage and the scale of the map on which the lineaments are picked. In general there is a sub-set of clearly defined 
lineaments within a larger set of subtle lineaments. Cordell (1989) found that interpreters do not agree and are therefore inconsistent in the identification of the subtler lineaments. There is a range of structural, stratigraphical and intrusive features that can give rise to magnetic lineaments. For example, a faulted offset in a magnetic unit will generate an anomaly, which follows the trace of the fault. Linearly extensive magnetic features such as dykes can commonly be observed over considerable distances within magnetic images. In some cases the signature of the anomalies may change along the lineament signifying that an underlying basement trend has exercised control over subsequent geological evolution. The lineaments presented here have been picked from shaded relief images illuminated from several different orientations and from images of the horizontal gradient and analytic signal. The lineaments are shown in Fig. 4 on a grey scale plot of the total magnetic field illuminated from the northeast.

\section{Palaeogene dykes}

The dominant lineament trend is northwesterly and these lineaments are concentrated in the northeast of the survey area. Some east-to-west trending lineaments are also observed, but these occur mainly in the northwest. Many of the north-westerly trending lineaments are caused by Palaeogene dykes. Some of these lineaments correlate with mapped dykes (e.g. L1), some digress suggesting that the mapped location may be in error (e.g. L2) whereas others indicate dykes in the sub-surface that were not previously known (e.g. L3). The majority of these appear as negative anomalies, indicating that the dominant magnetisation is a reverse remanent component. These Palaeogene dykes are assigned to the Mull Dyke Swarm (Bailey et al., 1924). Mussett et al. (1980) have shown from palaeomagnetic studies on Mull that the early lavas are reversely (R) magnetised with NRM (Natural Remanent Magnetisation) components of declination and inclination of approximately $182^{\circ}$ and $-58^{\circ}$ $[\mathrm{D}, \mathrm{I}]$ respectively. The intrusions of centres 1 and 2 are generally normally $(\mathrm{N})$ magnetised in a direction $\left[\mathrm{D}=352^{\circ}, \mathrm{I}=63^{\circ}\right]$ approximately that of the Earth's present field. The whole 
of the igneous activity on Mull can be contained within a polarity sequence R-N-R assuming overprinting, and a time scale of about 3.5 Ma at about $58 \mathrm{Ma}$. The distinctive geophysical character of the Palaeogene dykes demonstrates they are more frequent and of much greater lateral continuity than previously mapped. In the north-east and south-west of the survey area two or three times more dykes may be mapped from the new geophysical data and traced across the extent of the survey (compare Figs. 1 and 2 ).

One of the most prominent lineaments is L4, which has a mainly easterly orientation that turns north-westerly towards its western end. It may be possible to trace this feature towards the east as a series of offset segments. Although the lineament is more thatn $11 \mathrm{~km}$ in length it is only coincident with the occurrence of a Palaeogene dyke, as currently mapped, for less than one quarter of its length across parts of the Mauchline Basin. It is a sharply positive feature with amplitudes in the range 100 to $300 \mathrm{nT}$ that indicates it is likely to have a normal remanent component. A magnetic profile has been extracted across this feature (Profile 1 on Fig. 2) and is shown in Fig. 5. Depth-to-source estimations have been made using the twodimensional Werner deconvolution technique (Werner, 1949; Hartman et al., 1971; Ku \& Sharp, 1983). Werner deconvolution is considered by Rollin (in press) to give more reliable depth estimates for dykes than Euler deconvolution as the horizontal and vertical derivatives of the anomaly are utilised. Application of the technique generated reliable depth-to-source estimations ranging from 78 to $108 \mathrm{~m}$ below ground level. This is an unexpected result as the dyke crops out at surface. It most likely indicates that either the dyke is less magnetic near surface due to weathering or that the width of the dyke increases with depth so that the main source of the anomaly is not near surface. This has been further explored with a two dimensional model using the GRAVMAG modelling program (Busby, 1987; Pedley, 1991). A dyke has been created perpendicular to the profile (see Fig. 5) that has a magnetic susceptibility of 0.009 SI. It has been assigned a normal remanent magnetic component with a declination and inclination [D, I] of $14^{\circ}$ and $71^{\circ}$, respectively, as reported by Dagley \& 
Mussett (1978) for dykes on Mull. The modelled remanent intensity is $1.1 \mathrm{~A} \mathrm{~m}^{-1}$. This model is not unique, but it does demonstrate that the width of the dyke increases with depth. In the model the dyke has a measured width of $18 \mathrm{~m}$ at outcrop [NS 698 361] that increases to $90 \mathrm{~m}$ at depths below $160 \mathrm{~m}$. Such a width at depth is unlikely and may result from a change in magnetic remanent intensity with depth or may indicate more than one dyke at depth.

Mineral reconnaissance activities in the Mauchline area have concluded that there are notably high values of gold within the Mauchline Basin and that mineralisation may be associated with magnetic lineaments of north-west trend (Leake et al., 1997). Leake et al. (1997) suggested that the magnetic lineaments indicate deep-seated faults and any new data that supports the presence of faults would be of great interest. However, the character of the linear anomalies from this more highly resolved magnetic data suggests they are due to the presence of dykes rather than faults. This is supported by consideration of the concentration of arsenic, antimony and tin values from analysis of stream sediments from the Mauchline area (BGS, 1997) by Breward et al. (2004) who conclude that the gold concentrations were reworked 'placer' deposits rather than mineralisation within fractures.

Werner deconvolution has been applied to a further nine long profiles that cross, at a high angle, all the major linear negative magnetic anomalies. Reliable solutions indicate depth to magnetic sources of greater than $100 \mathrm{~m}$ below the ground surface. Fig. 6 shows the negative magnetic anomaly over a Palaeogene dyke that is $24 \mathrm{~m}$ wide at outcrop (Profile 2 on Fig. 2). It has also been modelled as a two dimensional dyke, striking perpendicular to the profile. It has been assigned a reverse remanent magnetisation with components $\mathrm{D}=182^{\circ}$ and $\mathrm{I}=-58^{\circ}$ (Mussett et al., 1980) and a modelled intensity of $3.7 \mathrm{~A} \mathrm{~m}^{-1}$. Its magnetic susceptibility, which generates a normal induced component, is 0.025 SI. Once again, this is not a unique model, but it indicates that the dyke may widen from a measured outcrop width of $24 \mathrm{~m}$ to 60 $\mathrm{m}$ at depths below $200 \mathrm{~m}$. 
Some of the lineaments interpreted as Palaeogene dykes display offsets along their length, e.g. L5. Many of these offsets probably occur as the dykes change course when intersecting a crosscutting structure such as a fault or igneous intrusion. However, the possibility remains that some offsets have resulted from the reactivation of existing faults. Of particular note is a north-to-south trending lineation that is split into three segments (L6, L7 and L8) by crosscutting easterly trending lineaments. This lineation has an unusual trend when compared to the Permo-Carboniferous easterly trending dykes and northwesterly trending Palaeogene dykes. It is of short wavelength, has a mainly negative character with a low amplitude of maximum value around 65 nT. Both of the offsets coincide with known faults (Fig. 1), the Inchgotrick and Loudon Castle faults to south and north, respectively (Anderson, 1925). Displacement across the Inchgotrick Fault as early as Silurian times is evident by uplift and erosion of footwall block formations of the Waterhead and Dungavel groups prior to deposition of unconformable Siluro-Devonian Lanark Group strata (Macpherson et al., 2000). Variations in the thickness of strata across the fault demonstrate Lower Carboniferous syndepositional fault movement (Richey et al., 1930; Monro, 1999) and it also displaces Upper Carboniferous rocks (British Geological Survey, 2002a \& b). The simplest explanation of this feature is a minor Palaeogene dyke that has changed course at the pre-existing crosscutting faults in an offset en echelon pattern (cf. Dagley et al., in press).

\section{Permo-Carboniferous dykes}

There is a great abundance of basaltic and doleritic dykes of easterly trend mapped in the north-west of the survey area (BGS, 2002a, 2005) but not shown on Fig. 1. The dykes are proved mainly in underground mine workings although the timing of intrusion is poorly constrained (Devonian to Palaeogene). They are less than $10 \mathrm{~m}$ wide and 1 to $4 \mathrm{~km}$ in length, intruded along faults and are commonly spaced less than $100 \mathrm{~m}$ apart, but they not well resolved in Fig. 2. There are a number of potential reasons for this: the dykes may have only a low magnetic susceptibility; the resultant magnetisation arising from the induced and 
remanent components may be small; and, the orientation of the flight lines is west to east and so consequently many east-west striking, low amplitude anomalies cannot be resolved. Rollin (in press) reports the results of 155 volume magnetic susceptibility measurements on PermoCarboniferous dykes from southern Scotland. These have a range of 0.016 to 0.052 SI with a mean of 0.033 SI (comparable values for Palaeogene dykes are a range of 0.001 to 0.073 SI with a mean of $0.025 \mathrm{SI})$.

Forward modelling of the magnetic response of an easterly striking Permo-Carboniferous dyke was undertaken, assigning it a magnetic susceptibility of 0.033 SI and several widths and depths to the top surface from ground level. At a flight altitude above ground level of 56 $\mathrm{m}$, a one metre wide dyke should generate an anomaly of $4 \mathrm{nT}$ for a depth to the top surface of $5 \mathrm{~m}$. This is a small anomaly but it is within the detectable range of modern highresolution surveys, although the anomaly might be difficult to resolve on an east-to-west flight line. For $5 \mathrm{~m}$ and $10 \mathrm{~m}$ wide dykes the peak response increases to 15 and $30 \mathrm{nT}$, respectively, for a depth to the top surface of $5 \mathrm{~m}$. This reduces to 12 and $24 \mathrm{nT}$, respectively, when the depth to the top surface increases to $20 \mathrm{~m}$. Hence, some of the PermoCarboniferous dykes may not generate anomalies due to low magnetic susceptibility, but some anomalies would be expected given the range of measured values. Carboniferous basalts and intrusions often have low remanent magnetic intensities (Rollin, in press). The Midland Valley Sill has a strong and stable NRM (natural remanent magnetisation) with a vector direction of $\left[\mathrm{D}=175^{\circ}, \mathrm{I}=14^{\circ}\right]$ (Milton, 1972) and a Carboniferous dyke near Dunbar also give a stable NRM vector southwards and upwards [D $=194^{\circ}, \mathrm{I}=19^{\circ}$ ] (Xu \& Tarling, 1987). Most results from the British Carboniferous indicate a reversed polarity in the Tournaisian, Visean and Westphalian (Palmer et al., 1985), and hence, the induced and remanent magnetic vectors are opposed. Consequently low to moderate remanent intensities that are in opposition to similar magnitude induced intensities may result in a weak resultant 
magnetic vector. This, coupled with the east to west orientated flight lines may explain the lack of large anomalies arising from the Permo-Carboniferous dykes.

\section{Trace of the Clevelend Dyke}

The Cleveland Dyke is a Palaeogene intrusion that appears to extend for $430 \mathrm{~km}$ from Mull to the coast of northeast England. First recognised by Teall (1884) with elaborations by Tyrrell (1917) and Holmes and Harwood (1929), the dyke was considered to be a single, comagmatic body with a northern (Midland Valley) and southern section. MacGregor (1930; 1949) suggested that the sections may form a single, unified dyke but he identified a third section in order to explain the behaviour of the dyke near the Southern Upland Fault. These three sections have become referred to as the Stevenston-Coylton, New Cumnock and Cleveland dykes, respectively (MacDonald et al., 1988). The Stevenston-Coylton section, which crosses the Midland Valley, is shown on the 1:50 000 geological map (British Geological Survey, 2005) as the Cumbrae-Stevenston Dyke (Monro, 1999) (Fig. 1).

MacDonald et al. (1988) performed petrographic, mineralogical and geochemical analyses on samples from along the sections of dykes. They concluded that the northern two segments are not comagmatic with the Cleveland Dyke, but they can be correlated together and hence the Cleveland Dyke cannot be traced directly to Mull despite the composition being virtually identical to tholeitic basalt lavas from Mull. Examination of Fig. 4 shows that the CumbraeStevenston Dyke is associated with some weak lineaments (L9 to L13), although it is not clear if these can be correlated together as representing a single causative body. Lineament L14 (and with a small offset across the Kerse Loch Fault, L15) forms a distinctive southeast trending lineament that is associated with a reversely magnetised feature. Their location correlates well with a northwesterly extension of the trace of the Clevelend Dyke from the Southern Uplands. Recent ground magnetic evidence (Dagley et al., in press) indicates that the Cleveland Dyke is associated with large, reversely magnetised anomalies that would be 
consistent with lineament L14. The trend of this lineament links directly to magnetic anomalies measured by Dagley et al. (in press) $1.25 \mathrm{~km}$ north of the Southern Upland Fault, interpreted as representing the Cleveland Dyke. Hence, as concluded by Dagley et al. (in press), the New Cumnock Dyke situated some $16 \mathrm{~km}$ to the east is not the same as the Cleveland Dyke. Thus lineament L14 appears to represent the Cleveland Dyke, which does not crop out at the present surface across the Midland Valley. However, a basalt dyke has been mapped underground in the Ayr Hard Coal Seam [2374 6234] (British Geological Survey, 2001). This area is part of Prestwick and so was not covered by the airborne survey, but a continuation of lineament L14 would be very close to this underground mapped dyke.

\section{Volcanic vents and plugs}

Volcanic vents and plugs are recognised in the study area. Anomaly O in Fig. 2 is an example of a magnetic anomaly that corresponds with a mapped Permo-Carboniferous volcanic vent or plug rocks. The anomaly has distinctive positive and negative lobes indicating an isolated source. The strong negative lobe to the south indicates that the feature is reversely magnetised. However, it should be noted that not all vents and plugs are associated with magnetic anomalies. Anomalies of this shape can arise from other sources, but an attempt has been made to pick the most likely anomalies indicating a vent or plug and these are shown on Fig. 4 as open or crossed circles. Of the 22 anomalies identified, 19 indicate reverse magnetisation (open circles) whereas only three are normally magnetised (crossed circles). The three normally magnetised anomalies and 12 of the reversely magnetised anomalies do not show a correlation with the outcropping geology indicating a possible vent or plug concealed beneath superficial deposits. Of the remaining reversely magnetised anomalies, six correspond with mapped Permo-Carboniferous volcanic vents or plugs whilst one correlates with a Palaeogene sill.

\section{Conclusions}


New high-resolution aeromagnetic data surveyed by flight lines spaced at 200 m over central Ayrshire have led to a greatly enhanced imaging of shorter wavelength features that was not possible in existing data recorded along $2 \mathrm{~km}$ spaced flight lines. Hence, the distribution of extrusive and intrusive igneous rocks in the near sub-surface is more accurately defined. The marked contrast in the magnetic character across the Inchgotrick Fault indicates that the Clyde Plateau Volcanic Formation is not only present at outcrop but underlies the Upper Carboniferous sequence in the hangingwall sequence to the north and confirms it is not present to the south of the fault (Monro, 1999).

Intrusions that make up the Distinkhorn Plutonic Complex are part of a single igneous body at depth that has well-defined western, northern and southern boundaries. The poorly defined eastern boundary indicates increasing depth of burial of the Distinkhorn igneous rocks.

The differing magnetic characters of fault-defined blocks bounded by the Glenmuir, Kennox and Southern Upland faults is evident from the high-resolution data. In detail, the magnetic anomalies do not correspond to the distribution of the Duneaton Volcanic Formation mapped at outcrop. Concealed rocks of a highly magnetic character, analogous to those of the Ballantrae Complex, may make a partial contribution to the magnetic anomalies as noted along strike to the southwest.

Northwesterly trending lineaments are clearly defined and most can be attributed to Palaeogene dykes, the majority of which are reversely magnetised. Palaeogene dykes are two or three times more common in areas of the survey and of greater continuity than previously mapped. Depth to source solutions and modelling suggest that although the dykes have a limited width at outcrop, their widths increase with depth, or in some instances there may be more than one dyke at depth.

In the Mauchline area the relatively high numbers of gold grains in stream sediments (Leake et al., 1997) has been attributed to the possible presence of deep-seated geological faults 
inferred from previous magnetic survey data. The high-resolution magnetic data supports dykes not faults as the source of the linear magnetic anomalies and the conclusion of Breward et al. (2004) that the gold concentrations were not derived from mineralisation within fractures.

Permo-Carboniferous easterly trending dykes are not well resolved in the new aeromagnetic data. It is likely that the combination of induced and remanent magnetic components results in a low amplitude resultant magnetic vector. This, combined with the easterly oriented flight lines, may explain the lack of large anomalies arising from these dykes.

It is likely that one of the many prominent north-westerly trending lineaments in the southwest of the area is due to the trace of the Palaeogene Cleveland Dyke across the Midland Valley. Its lack of outcrop explains why the Cumbrae-Stevenston Dyke has previously been, erroneously, correlated with the Cleveland Dyke.

\section{Acknowledgements}

This paper is published by permission of the Executive Director of the British Geological Survey (NERC). The authors are grateful for the comments of the two reviewers Mike Browne and Brian Bell.

\section{References}

ANDERSON, E.M. 1925. The economic geology of the Ayrshire Coalfields Area II. (Geological Survey, Scotland: HMSO, Edinburgh).

BAILEY, E.B., CLOUGH, C.T., WRIGHT, W.B., RICHEY, J.E. \& WILSON, G.V. 1924. Tertiary and post-Tertiary Geology of Mull, Loch Aline and Oban. Memoir of the Geological Survey of Great Britain. 
BELL, B.R. \& WILLIAMSON, I.T. 2002. Tertiary Igneous Activity. In: Trewin, N.H. (ed.) The Geology of Scotland. The Geological Society, London, 371-407.

BREWARD, N., AKHURST, M.C., \& STONE, P. 2004. Cryptogeology. Regional geochemistry as an aid to geological mapping. Earthwise issue 20, British Geological Survey.

BRITISH GEOLOGICAL SURVEY. 1997. Regional geochemistry of southern Scotland and part of northern England. (Keyworth, Nottingham: British Geological Survey).

BRITISH GEOLOGICAL SURVEY. 1998. Colour Shaded Relief Magnetic Anomaly Map of Britain, Ireland and adjacent areas (compilers C P Royles \& I F Smith) 1:1 500000 scale (Keyworth, Nottingham, United Kingdom, British Geological Survey).

BRITISH GEOLOGICAL SURVEY. 1999a. New Cumnock. Scotland Sheet 15W. Solid Geology. 1:50 000. (Keyworth, Nottingham: British Geological Survey).

BRITISH GEOLOGICAL SURVEY. 1999b. New Cumnock. Scotland Sheet 15W. Solid and Drift Geology. 1:50 000. (Keyworth, Nottingham: British Geological Survey).

BRITISH GEOLOGICAL SURVEY. 2001. Sheet NS32SE Ayr. Solid Geology. 1:10 000. (Keyworth, Nottingham: British Geological Survey).

BRITISH GEOLOGICAL SURVEY. 2002a. Kilmarnock. Scotland Sheet 22E. Solid Geology. 1:50 000. (Keyworth, Nottingham: British Geological Survey).

BRITISH GEOLOGICAL SURVEY. 2002b. Kilmarnock. Scotland Sheet 22E. Solid and Drift Geology. 1:50 000. (Keyworth, Nottingham: British Geological Survey).

BRITISH GEOLOGICAL SURVEY. 2005. Irvine. Scotland Sheet 22W and part of 21E. Solid Geology. 1:50 000. (Keyworth, Nottingham: British Geological Survey).

BUSBY, J.P. 1987. An interactive FORTRAN 77 program using GKS graphics for 2.5D modelling of gravity and magnetic data. Computers and Geosciences, 13, 639- 644. 
CORDELL, L. 1989. Experiments in the phenomenology of geophysical lineaments. 125128 In: Regional geophysical lineaments - their tectonic and economic significance. Qureshy, M.N. \& Hinze, W.J. (editors), Memoir of the Geological Society of India, No.12.

DAGLEY, P. \& MUSSETT, A.E. 1978. Palaeomagnetism of the Fishnish dykes, Mull, Scotland. Geophysical Journal of the Royal Astronomical Society, 53, 553-558.

DAGLEY, P., SKELHORN. R.R., MUSSETT, A.E., JAMES, S. \& WALSH, J.N. (in press). The Cleveland Dyke in southern Scotland. Scottish Journal of Geology.

FLOYD, J.D. 1999. Geology of the Carrick-Loch Doon district. Memoir of the British Geological Survey, Sheets 8W and 8E (Scotland).

HALL, J. 1974. A seismic reflection survey of the Clyde Plateau Lavas in North Ayrshire and Renfrewshire. Scottish Journal of Geology, 9, 253-279.

HARTMAN, R.R., TESKEY, D.J., \& FRIEDBERG, J.L. 1971. A system for rapid digital aeromagnetic interpretation. Geophysics, 36, 891-918.

HOLMES, A. \& HARWOOD, H.F. 1929. The tholeiite dykes of the north of England. Mineralogical Magazine, 22, 1-52.

KORHONEN, J.V. 2005. Airborne magnetic method: Special features and review of applications. In: Airo, M-L (ed) Aerogeophysics in Finland 1972 - 2004: Methods, system characteristics and applications., Geological Survey of Finland, Special Paper, 39, 77-102.

KU, C.C \& SHARP, J.A. 1983. Werner deconvolution for automated magnetic interpretation and its refinement using Marquardt's inverse modeling. Geophysics, 48, 754774.

LEAKE, R.C., CAMERON, D.G., BLAND, D.J., STYLES, M.T., \& FORTEY, N.J. 1997. The potential for gold mineralisation in the British Permian and Triassic red beds and their 
contacts with underlying rocks. Mineral Reconnaissance Programme Report, British Geological Survey, No. 144.

MACDONALD, R., WILSON, L., THORPE, R.S. \& MARTIN, A.1988. Emplacement of the Cleveland Dyke: Evidence from geochemistry, mineralogy and physical modelling. Journal of Petrology, 29, 559-583.

MACGREGOR, A.G. 1930. Dykes of post-Carboniferous age. In: The geology of North Ayrshire. Memoir of the Geological Survey of Great Britain, 289-315.

MACGREGOR, A.G. 1949. Dykes of post-Carboniferous age. In: The geology of Central Ayrshire. Memoir of the Geological Survey of Great Britain, 118-123.

MACPHERSON, K.A.T., SMITH, R.A. \& AKHURST, M.C. 2000. Geology of the Kilmarnock district. Sheet description of the British Geological Survey, 1:50 000 Series Sheet 22E (Scotland).

MCLEAN, A. C. 1966. A gravity survey in Ayrshire and it's geological interpretation. Scottish Journal of Geology, 9, 253-279.

MILTON, J.J.W. 1972. A palaeomagnetic study of Permian and Carboniferous igneous rocks from the Midland Valley of Scotland. Unpublished MSc thesis, University of Newcastle on Tyne.

MONAGHAN, A.A. \& PARRISH, R.R. 2006. Geochronology of Carboniferous-Permian magmatism in the Midland Valley of Scotland: implications for regional tectonomagmatic evolution and the numerical time scale. Journal of the Geological Society, London, 163, 1528.

MONAGHAN, A.A \& PRINGLE, M.S. 2004. ${ }^{40} \mathrm{Ar} /{ }^{39} \mathrm{Ar}$ geochronology of CarboniferousPermian volcanism in the Midland Valley of Scotland. In: Wilson, M., Neumann, E-R, Davies, G.R, Timmerman, M.J., Heermans, M. \& Larsen, B.T. (eds.) Permo-Carboniferous 
Magmatism and Rifting in Europe. Geological Society, London, Special Publications, 223, 219-241.

MONRO, S.K. 1999. Geology of the Irvine district. Memoir of the British Geological Survey, Sheet 22W and part of Sheet 21E (Scotland).

MUSSETT, A.E, DAGLEY, P. \& SKELHORNE, R.R. 1980. Magnetostratigraphy of the Tertiary igneous succession of Mull, Scotland. Journal of the Geological Society of London, 137, 349-357.

PALMER, J.A. PERRY, S.P.G. \& TARLING, D.H. 1985. Carboniferous magnetostratigraphy. Journal of the Geological Society London, 142, 945-955.

PEDLEY, R.C. 1991. GRAVMAG User Manual: Interactive 2.5D gravity and magnetic modelling program. (Keyworth, Nottingham, U.K: British Geological Survey).

RICHEY, J.E., ANDERSON, E.M. \& MACGREGOR, A.G. 1930. The geology of north Ayrshire. Memoir of the Geological Survey, Scotland, Sheets 22.

READ, W.A., BROWNE, M.A.E., STEPHENSON, D. \& UPTON, B.G.J. 2002. Carboniferous. In: Trewin, N H. (ed.) The Geology of Scotland. The Geological Society, London, 251-299.

ROLLIN, K. E. in press. Regional Geophysics of Northern Scotland. Version 1.0. on CDROM (Keyworth, Nottingham: British Geological Survey).

SMITH, R.A. 1999. Geology of the New Cumnock area. Sheet description of the British Geological Survey, 1:50 000 Series Sheet 15W New Cumnock (Scotland). 37 p.

TEALL, J.H. 1884. Petrological notes on some North-of-England dykes. Quarterly Journal of the Geological Society of London, 40, 209-640.

THIRLWALL, M.F. 1988. Geochronology of Late Caledonian Magmatism in northern Britain. Journal of the Geological Society, London, 145, 951-967. 
TYRRELL, G.W. 1917. Some Tertiary dykes of the Clyde area. Geological Magazine, 4, 305-315.

WERNER, S. 1949. Interpretation of magnetic anomalies as sheet-like bodies. Sveriges Geologiska undersokning, Ser C, Arsbok 43, No. 6, Stockholm.

XU, T.C. \& TARLING, D.H. 1987. A palaeomagnetic study of the intrusions and Carboniferous sediments at Dunbar, Scotland. Scottish Journal of Geology, 23, 39-48. 


\section{Figure captions}

Fig. 1. The geographical and geological setting and extent of the high-resolution aeromagnetic survey in central Ayrshire. IF, Inchgotrick Fault; LCF, Loudon Castle Fault; KLF, Kerse Loch Fault; BHF, Bankhead Fault; GMF, Glenmuir Fault; KXF, Kennox Fault; SUF, Southern Upland Fault. C-SD, Cumbrae-Stevenston Dyke.

Fig. 2. Colour shaded relief image of the high-resolution aeromagnetic data illuminated from the northeast. The data are displayed relative to the International Geomagnetic Reference Field in nanoTesla (nT). The annotation A to O refers to anomalies that are discussed in the text; P1 and P2 are the locations of profiles where magnetic modelling has been undertaken.

Fig. 3. Colour shaded relief image, illuminated from the northeast, of the old aeromagnetic data for the region. The data are displayed relative to a variant of the International Geomagnetic Reference Field 1990. The polygon outlines the extent of the new highresolution survey. The data are displayed in nanoTesla (nT).

Fig. 4. Picked magnetic lineaments overlain on a grey shaded image of the high-resolution aeromagnetic data illuminated from the northeast. Also shown are the picked locations of anomalies that can be interpreted as indicating a volcanic vent or plug. Crossed circles indicate a normally magnetised vent or plug, whereas open circles indicate reverse magnetisation.

Fig. 5. Two dimensional model of a dyke along magnetic Profile 1, the location of which is shown on Fig. 2. The dyke has magnetic properties of susceptibility 0.009 SI, a normal remanent magnetic component with a declination and inclination of $14^{\circ}$ and $71^{\circ}$, respectively, and a remanent intensity of $1.1 \mathrm{~A} \mathrm{~m}^{-1}$. The anomaly was calculated on a surface at the altitude of the aircraft that is not shown in the figure.

Fig. 6. Two dimensional model of a dyke along magnetic Profile 2, the location of which is shown on Fig. 2. The dyke has magnetic properties of susceptibility $0.025 \mathrm{SI}$, a reverse 
remanent magnetic component with a declination and inclination of $182^{\circ}$ and $-58^{\circ}$, respectively, and a remanent intensity of $3.7 \mathrm{~A} \mathrm{~m}^{-1}$. The anomaly was calculated on a surface at the altitude of the aircraft that is not shown in the figure. 


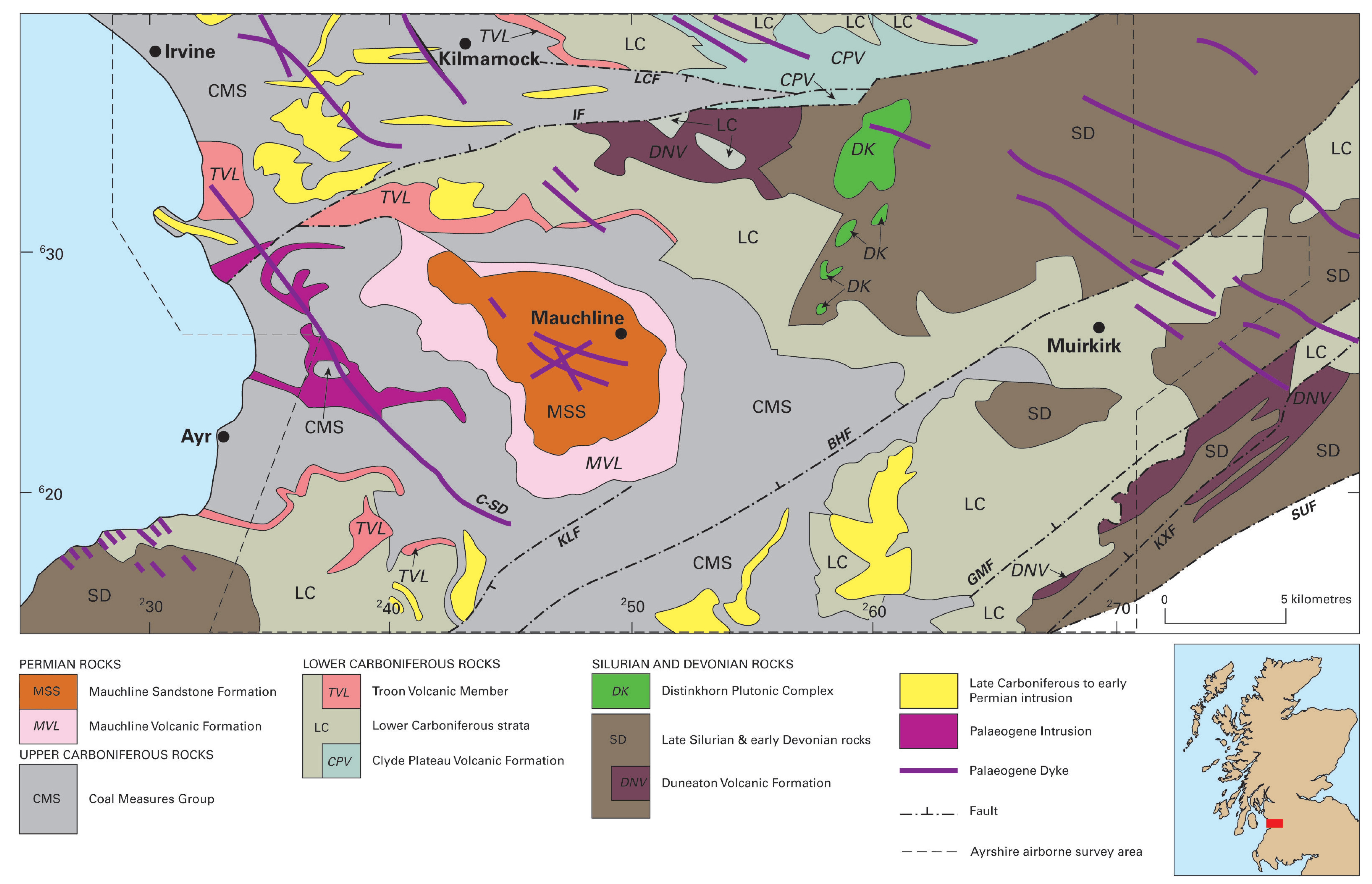




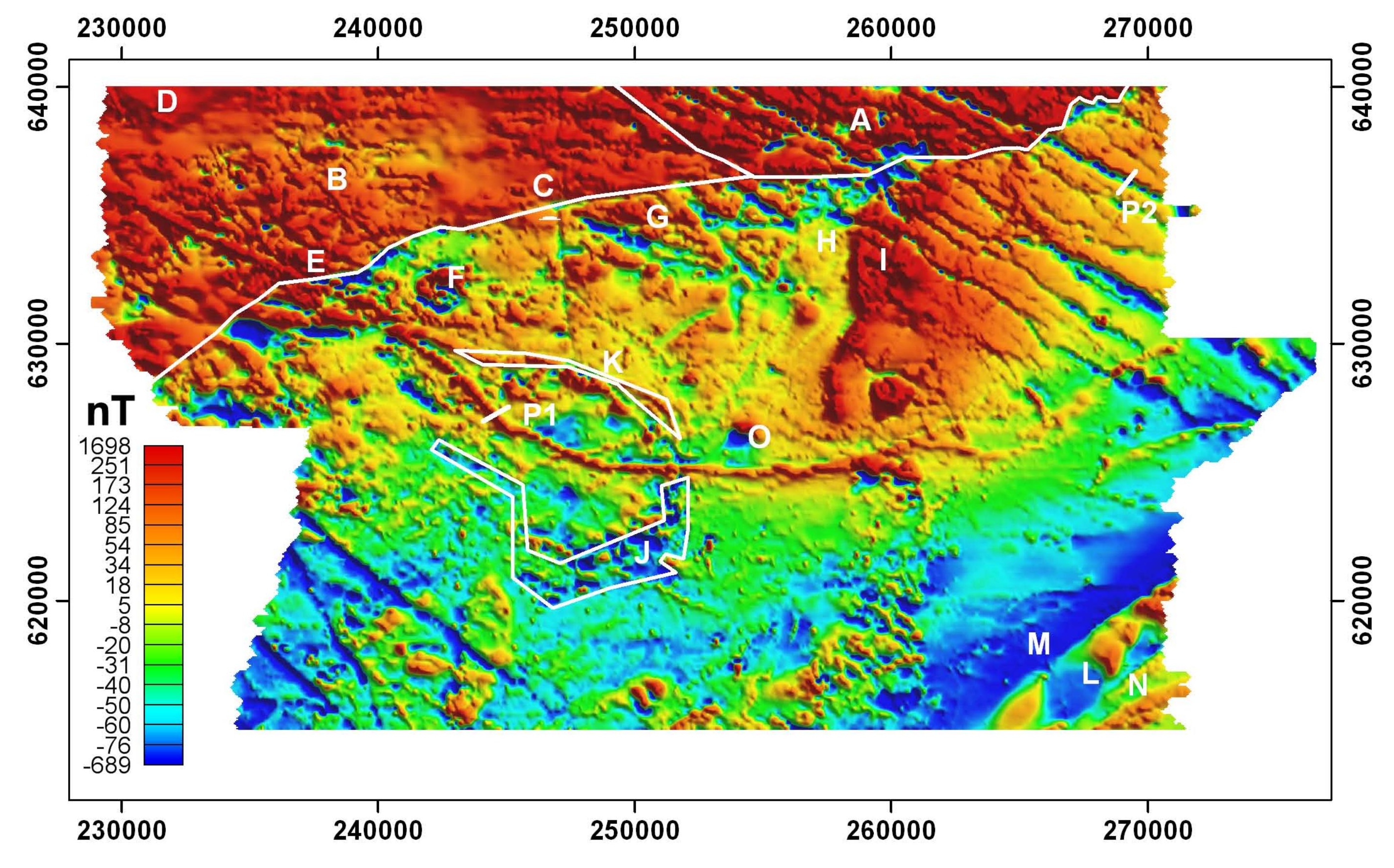




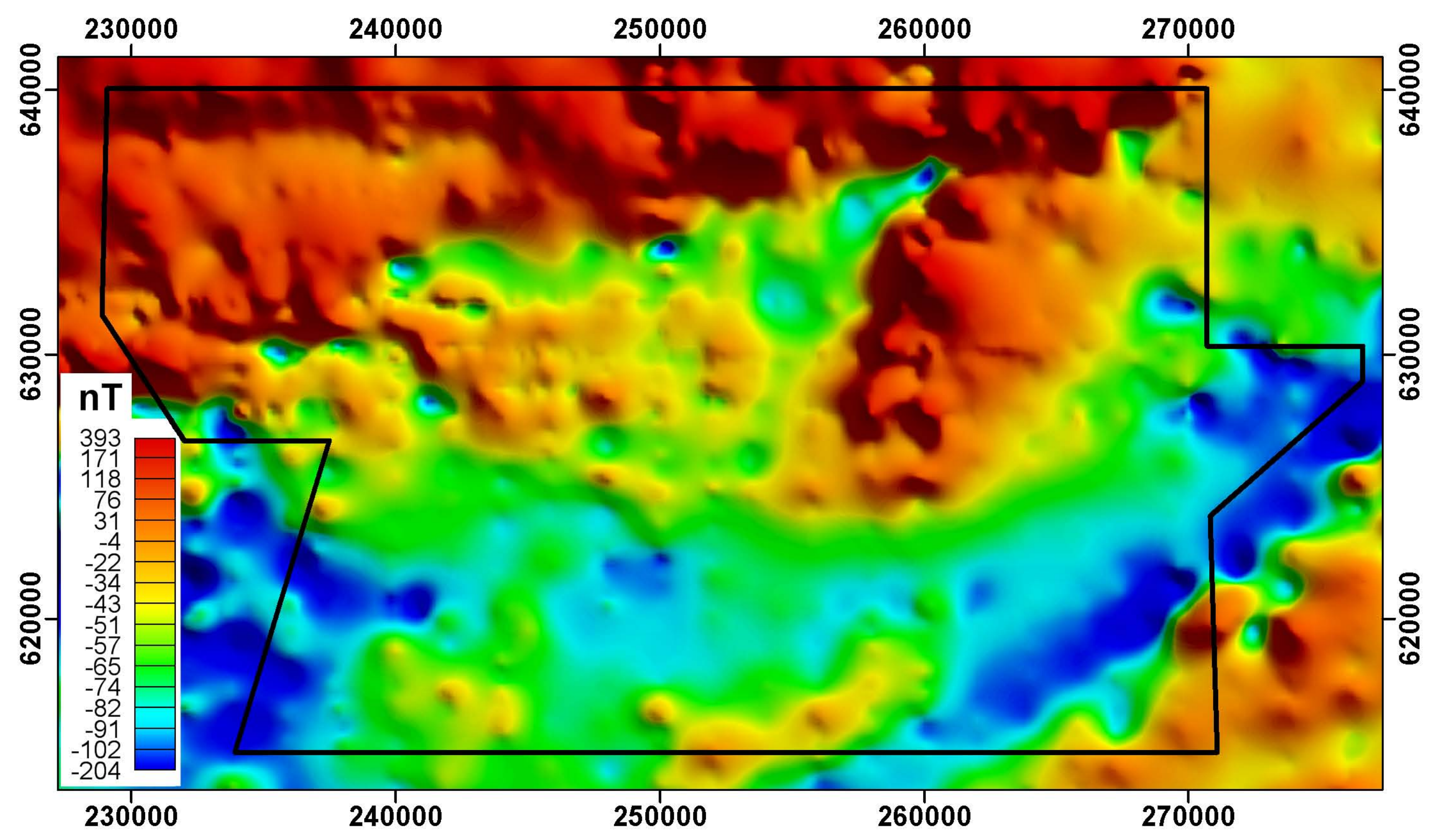




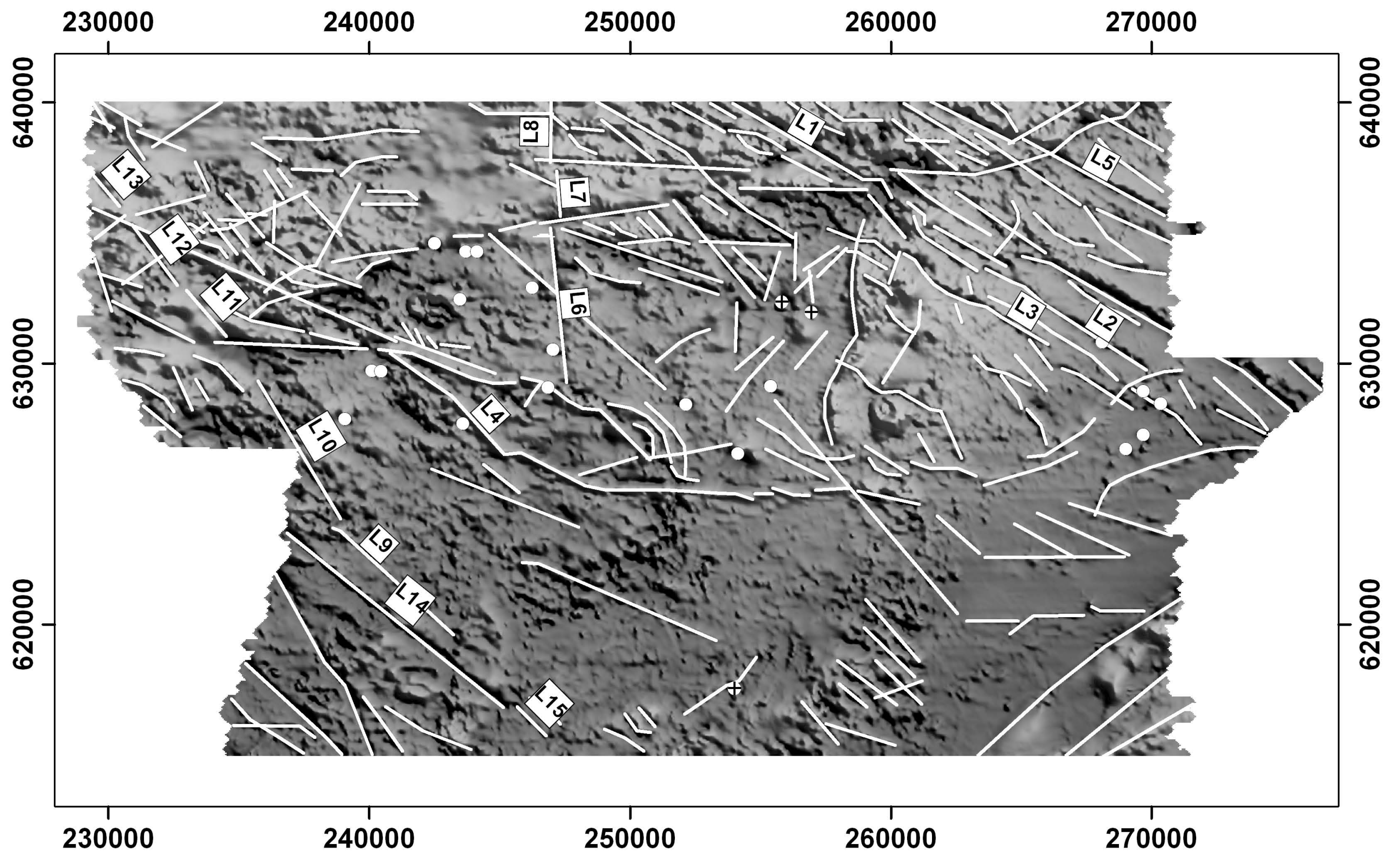


